\title{
Monitoring and Evaluation Processes Critical to Service Provision in South Africa's Rural-Based Municipalities
}

\author{
Betty C. Mubangizi*
}

\author{
School of Management, IT and Governance, University of KwaZulu-Natal, South Africa
}

\begin{abstract}
South African municipalities are at the coalface of service provision, with communities relying on municipal performance for life-impacting services. The impact of effective service delivery or the lack thereof is particularly significant for the poor who generally lack safety nets to cushion themselves against the inadequacies of poorly resourced, mainly rural, municipalities. Although municipalities are distinct entities, they rely on other levels of government for important resources. Further, municipalities draw on the support of other non-government actors to provide public services. In such a scenario, where variously positioned actors contribute to the attainment of the public good, the role of monitoring and evaluation (M \& E) is critical as it ensures compliance by each of the role-players in the effective delivery of basic services to communities. What are the complexities of service delivery and the processes through which $M$ \& E takes place in rural municipalities? How are the beneficiaries of municipal services included in $M$ \& $E$, and what might be the critical contributors to a functional and all-inclusive $M \& E$ process in rural-based municipalities? This conceptual paper, posited in complex systems theory, draws on relevant literature to answer these questions. The conclusion drawn is that while current $\mathrm{M} \& \mathrm{E}$ process are, mainly, monitored through statutory structures; non-statutory structures formed out of ad hoc self-organising models can provide useful forums for monitoring municipal service provision for sustainable livelihoods.
\end{abstract}

Keywords: Rural municipalities, partnerships in service provision, monitoring and evaluation, community participation.

\section{STATE OF LOCAL GOVERNMENT IN SOUTH AFRICA}

To understand the challenges that rural municipalities are faced with and the need for a unique monitoring and evaluation ( $M \& E$ ) model, it is necessary to get an understanding of the state of local government in the country. South Africa comprises 278 municipalities. Of these, 8 are metropolitan, 44 are district and 226 are local municipalities. Many of these local municipalities are in small towns with a vast hinterland of small villages. Municipalities have the mandate to focus on growing local economies and providing infrastructure and basic services. While municipalities draw on the national government to provide the much needed finances to provide infrastructure and services, it is expected that municipalities fund their mandated responsibilities. Being the sphere of government closest to the people, it is to be expected that a core function of municipalities is the rendering of a variety of basic but essential services to the community within their jurisdiction (Koma 2010:113). The mandate of South African municipalities is succinctly captured in key legislation and policies.

The provision of services by municipalities is a constitutional obligation. Part B of Schedule 5 of South

\footnotetext{
*Address correspondence to this author at the NRF/Research Chair in Sustainable Local (Rural) Livelihoods. School of Management, IT and Governance, University of KwaZulu-Natal, South Africa; Tel: +27312603557; E-mail: Mubangizib@ukzn.ac.za
}

Africa's Constitution - concerning functions falling concurrently within the national and provincial competence constituent units - identifies the following services within the ambit of local government (LG) and municipalities: water; electricity; town and city planning; road and storm-water drainage; waste management; emergency services such as fire fighting; provision of licences; fresh produce markets; parks and recreation; security; libraries; and economic planning. Part B of Schedule 4 of the Constitution further identifies the following areas to be the responsibility of municipalities: air pollution; building regulations; child-care facilities; and electricity and gas reticulation - in addition to local tourism; municipal airports; municipal planning; municipal health services; municipal public transport; and municipal public works (RSA 1996).

Furthermore, the mandate for $L G$ is explicit in the preamble to the Local Government: Municipal Structures Act, 1998 (Act 117 of 1998) as:

A vision of democratic and developmental local government in which municipalities fulfil their constitutional obligations to ensure sustainable, effective and efficient municipal services, promote social and economic development, encourage a safe and healthy environment by working with communities in creating environments and human settlements in which all our people can lead uplifted and dignified lives. 
Lastly, the White Paper on LG asserts that "basic services enhance the quality of life of citizens and increase their social and economic opportunities by promoting health and safety, facilitating access to work, to education, to recreation and stimulating new productive activities" (Ministry for Provincial and Constitutional Development 1998:92).

All these legal and policy expectations of municipalities require funding, and a good revenue base is vital for municipalities to function effectively and efficiently. In highlighting the fundamental problem in the finances of local municipalities, Steytler (2005:199) points out that, at $80.6 \%$, the operating expenditure of local municipalities accounts for the bulk of their budgets - with the paltry remainder devoted to capital budgets. Steytler further points out that, of the operating budgets, salaries of municipal workers take up the largest share at $32.9 \%$, and yet LG receives only $17 \%$ of its revenue from national government. There is a further source of revenue for municipalities in the form of grants and an equitable share of revenue raised nationally. However, there is significant pressure on LGs to raise their own revenue and become selfsufficient - and herein lies the challenge for most ruralbased municipalities.

Several urban-based municipalities have a good revenue base in the form of property rates, service payments and other taxes. However, as observed in a 2009 Cooperative Government and Traditional Affairs (COGTA) report:

Local Municipalities are very vulnerable both from a revenue generation and from an institutional development perspective. They are located in economically depressed areas and have difficulty in attracting and retaining skilled managers, professionals, and technicians. It follows that some of these municipalities are seriously challenged to fulfil their obligations. They may be financially nonviable, articulate distress via heightened levels of community protests, and be particularly vulnerable to political control and poor institutional management and compliance (COGTA 2009:22-21).

There are other factors that typically prevent local municipalities from attaining self-sufficiency and effectively delivering on their mandate. A few are outlined below:

\subsection{Unfunded Mandates}

These occur when municipalities take on responsibilities they cannot perform, as is usually the case when municipalities are expected to implement policies crafted by national government. This legal framework is intended to prevent municipalities from receiving 'unfunded mandates', but as Atkinson (2003) notes, these measures do not guarantee adequate protection against unfunded mandates. These 'unfunded mandates' weaken municipalities financially and are a drain on local government's administrative capacity. A case in point is the indigent policy whose aim is to alleviate poverty in disadvantaged communities, by providing free basic water (at least 6 kilolitres per month), free basic electricity (at least 50 kWh per month), and subsidised sewerage and sanitation as well as solid waste management (Statistics SA 2017). Even with the equitable share from national revenue that municipalities receive, it severely constrains those municipalities (mainly ruralbased) that have a significantly high level of indigents (Arntz, Botes, and Bekker 2003).

\subsection{Skills Shortage}

While studying the profiles of several municipalities in South Africa, Koelble and LiPuma (2010) noted a severe skills shortage in financial and technical matters at the local level and a lack of enforcement mechanisms to oversee the financial processes of the municipalities. They further noted this was most visible in the poor and rural areas of the country. This was echoed by Robinson (2007), who, in recommending service improvement in municipalities, highlighted the value of a skilled resource base in municipalities advising that increasing efficiency and performance of poorly resourced municipalities requires requisite skills to manage complex planning, implementation, and $M$ \& E.

\subsection{Revenue Collection}

This relates to the amount of money collected as a percentage of the amount billed. Fjeldstad (2004:542) observes that revenue collection levels have worsened in many municipalities in recent years - despite the Masakhane campaign launched by government in 1995. The role of this campaign was to, inter alia, accelerate the delivery of basic services and housing, stimulate economic development in urban and rural areas, and promote the payment of municipal rent and service charges (Fjeldstad 2002). While the inability to 
pay for services is a significant part of low revenue collection levels, the credibility of the enforcement mechanisms and penalties imposed on defaulters affect citizens' ability to pay service charges. Enforcement mechanisms and the imposition of penalties all relate to a complex administrative process that many rural municipalities may not be privy to.

The disturbing state of municipalities in South Africa was recently articulated in the Attorney General of South Africa's (AGSA) 2018 Report. In May 2018, the AGSA reported an overall deterioration in the audit results of South Africa's municipalities for 2016-17. The report points to, inter alia, shortcomings in the development and maintenance of infrastructure. Specifically, the AGSA's audits identified several shortcomings in the development and maintenance of infrastructure by municipalities. These included the under-spending of grants, delays in project completion, poor quality workmanship, and inadequate monitoring of contractors:

These are symptoms of the larger problem that local government has with managing finances, performance and projects and with taking accountability for outcomes. Although funding and support are generally available from national government for the development and maintenance of municipal infrastructure, the non-delivery thereof at some municipalities and the impact on communities are the issues that need the most focused attention by all role players to ensure that the objective of a better life for all is achieved (AGSA 2018).

This directly impacts the wellbeing of the citizenry, in that it significantly affects the basic services of water, sanitation and transport - not to mention that less effort is directed to investment in resources for local economic development. A situation of this nature, where inadequate service delivery by poorly resourced municipalities is a result of a complexity of causes and where, by extension, the solution itself lies in collaboration by a complexity of actors - requires that the planning, implementation and $M$ \& $E$ be assiduously adhered to. We look to complex system theory to enable us to problematise $M$ \& $E$ mechanisms in poorly resourced, mainly rural, municipalities - with a view to operationalising possible solutions. A discussion of the complex systems theory now follows.

\section{THEORETICAL FRAMEWORK}

The complex systems theory is a helpful approach within which to frame an $M$ \& $E$ model for poorly resourced municipalities. Complex systems theory proposes that the world is affected by many variables that interact strongly with each other, unlike the more traditional systems theory that assumes that a few variables, interacting weakly with each other, determine the behaviour of actors and outcomes of activities within systems (Liebovitch 1998). For Svyantek and Brown (2000), this nonlinear view of systems used to describe complex systems' behaviour that originated in physics and chemistry, and is commonly known as chaos theory or complexity theory. As the discussion will show, South African municipalities, by necessity, engage in complex systems of horizontal and vertical partnerships in their pursuit of effective and efficient service provision. As Koch and Laurent (1999) advise, from a natural science perspective, explaining the behaviour of such a complex system requires an understanding of the variables determining the system's behaviour, the patterns of relationships among these variables, and the fact that these patterns and the strengths associated with each relationship may vary depending on the lifecycle and phase of the activities in the partnerships. Partnerships, by necessity therefore, exhibit multi-level and multiphase phenomena. Loorbach (2007) and Rotmans and Loorbach (2008) in Loorbach (2010: 167-168), have formulated several principles as a form of governance based on complexity theory. These principles offer insight into how $M$ \& $E$ could be best conceptualised. With respect to $M \& E$, the four main tenets are worth pointing out: Objectives should be flexible and adjustable at the system level. The complexity of the system is at odds with the formulation of specific objectives and blueprint plans. While being directed, the structure and order of the system are also changing, and so the objectives set should also change. Steering from the "outside" a societal system is not effective: Structures, actors, and practices adapt and anticipate, such that these should also be directed from "inside". A focus on (social) learning about different actor perspectives and a variety of options (which requires a wide playing field), is a necessary precondition for change. Participation from and interaction between stakeholders is a necessary basis for developing support for policies, but also for engaging actors in reframing problems and solutions through social learning.

Against this backdrop, the discussion proceeds to highlight areas in municipalities where multiple actors 
are drawn upon to deliver services. First, however, attention is drawn to the methodology used in the study.

\section{RESEARCH METHODOLOGY}

A qualitative research methodology was used, through content analysis. Thus, desktop research was used to explore how $M$ \& $E$ processes take place in municipalities and the critical contributors to a functional and all-inclusive $M \& E$ in rural municipalities. A review of books, journal articles, newspaper articles and internet sources was done, while the relevant texts were analysed thematically to help provide insight into the manner in which $\mathrm{M}$ \& $\mathrm{E}$ processes are being handled in rural communities, and the various challenges limiting their effectiveness.

\section{PARTNERSHIPS AND RELATIONSHIPS IN THE DELIVERY OF RURAL PUBLIC SERVICES}

In delivering on their mandate, municipalities draw on intergovernmental relations between the three spheres of government. Municipalities benefit from the oversight role of the provincial and national spheres and from financial transfers from national government including the much needed oversight role of the AGSA.

Partnerships in South Africa's municipalities have long been a modality in delivering services. Indeed, the White Paper on Local Government recommends that municipalities look for innovative ways of providing and accelerating the delivery of municipal services. It is in this regard that White Paper on Municipal Service Partnerships of 2004 provides a framework within which to leverage and marshal the resources of public institutions, CBOs, NGOs, and the private sector toward meeting the country's overall development objectives. Many writers having mused about the value and quality of such partnerships - see Farlam (2005); Akintoye, Beck, and Hardcastle (2008); and Ruiters and Matji (2016).

The main partnership arrangement municipalities engage in, is partnering with other levels of government through intergovernmental relations - as provided for in Section 41(2) of the Constitution (RSA 1996). The national sphere of government bears the responsibility of regulatory oversight. This sets the framework for general socio-economic development, and, specifically, the delivery of basic services. The provincial and local spheres have to fit into this policy framework. In addition, the national government provides some of the finances for service delivery, while provincial government oversees execution of the plans and programmes in the national government's policy framework. Lastly, the local government sphere is the implementing agent of those activities that specifically fall within the ambit of Schedule B, which was discussed earlier. Often, however, policy decisions are delegated to local municipalities, which are sometimes not adequately equipped to deliver the services.

However, this linear relationship is not the only one through which municipalities function. There is often a network of parties and stakeholders, and municipalities have dyadic linkages with many service providers external to them. In such partnerships in service delivery, agents like civil society organisations and private companies innovate to save costs, and thus develop capacity for future sub-contracting - so increasing their entrepreneurial confidence. At the same time, the image of LG improves. Awortwi (2003) emphasised the range of skills required by $L G s$ to improve governance of multiple forms of service delivery - for example, equipping staff with skills to manage contracts, implementing by-laws and sanctions, and improving negotiation skills to achieve better terms and build consensus as well as $M$ \& $E$ skills. A snapshot of areas where municipalities typically engage in partnerships is provided below:

\subsection{Provision of housing}

Provision of housing is a synchronised national and provincial competency. However, in many instances all three spheres of government take the responsibility even when it is not the task of LG (SA Cities Network 2007:12). Basic service delivery such as electricity, sanitation and water are the sole responsibility of municipalities and yet the delivery of these services has to fall within the policy framework of the national Departments of Energy and Department of Water Affairs respectively. The level of overlap and depth of grey areas in the responsibilities and functions of the three spheres suggests that one sphere's activity influences and determines the ability of local municipalities to effectively and efficiently deliver services.

\subsection{Delivery of Water and Sanitation}

Matibane (2010) studied improving service delivery through partnerships between LG, civil society and the private sector within Imizamo Yethu Township outside Stellenbosch in South Africa. It was observed that LG, civil society and the private sector could, through 
partnership, work together to mitigate the situation in the particular community - while further noting that many civil society organisations, business organisations and LG departments, although involved in service delivery and development in Imizamo Yethu, operate in isolation of each other (Matibane 2010:85). Forums by means of which local government, civil society organisations and business can work together should be formed. Such forums could assist in terms of devising a strategy to provide services, and disseminate information in a clear and structured manner. Furthermore, such forums would play the much needed oversight role for, as Ruiters and Matji (2016) advise, the lack of technical and financial skills and monitoring of the private operator are serious challenges.

\subsection{Formulation of Integrated Development Plans (IDPs)}

In a study on compliance with legislation, Ndzelu (2016), using Matatiele Local Municipality as a case study, noted that while many municipalities may be compliant when it comes to IDP legislation, there was an observable lack of capacity to plan for the long term and efficient project implementation. Ndlazi noted that some municipalities often employ external consultants and, through this partnership arrangement, manage to execute their legislative mandate of project planning and management tasks (Ndzelu 2016:73). Such partnership arrangements, useful as they might seem, can be viewed with suspicion because Ndzelu also observed the approach has been criticised by some officials, who "feel like the external service providers (partner) are trusted more than the officials themselves" (Ndzelu 2016). More fundamentally, however, when planning is done by an external consultant, the monitoring of such plans become problematic to implement as, while planning is cyclical and can be outsourced, the implementation, $M$ \& $E$ of such plans are, by necessity, routine and continuous.

The discussion on partnerships and outsourcing brings the important aspect of planning and implementation of service delivery projects and programmes - M \& E - into sharp focus. Given that rural municipalities require the support of, not only other levels of government, but also the support and involvement of extra government actors in the private sector and in civil society - it stands to reason there is a complex web of actors involved in the delivery of services, by necessity. This is a web whose actors and activities ought to be judiciously monitored, so that focus on outcomes is not lost.

\section{THE VALUE OF MONITORING AND EVALUATION}

Municipalities are faced with complex and diverse problems, due to high expectations from the various stakeholders to deliver on their mandate. To be more effective in service delivery, $M$ \& $E$ is a very important process that can enable projects and programmes to be delivered such that the outcome of these processes will make a meaningful impact on the intended communities (Maepa 2014).

The M \& E concept has been practised globally over the years (Boukeart 1994), in order to achieve an effective and sustainable socio-cultural economy through development; it is important that projects and programmes are effectively monitored and evaluated (Boukeart 1994). Globally, there has been increased pressure on governments and various stakeholders to become more responsible in relation to how the needs of their population are provided for through good governance, and be more accountable and transparent to promote effectiveness. Thus there is a move toward improved performance, which has necessitated the need to monitor and evaluate programmes and projects. As such, performance and evaluation is fast becoming a management tool used to improve activities of government to help achieve a viable outcome of development initiatives in the communities (Maepa 2014).

In South Africa, beginning from 2009, the government has, at central level, recognised the importance of $M$ \& $E$ as a transformational programme that could be used as a tool to transform socioeconomic programmes. This led to the establishment of the department of $M$ \& $E$ within the Presidency, charged with the mandate of ensuring that the various policies and reforms are implemented across the board (SA - The Presidency 2009). The OECD (2002) defines $M \& E$ as, firstly, monitoring being:

a continuing function that uses systematic collection of data on specific indices to provide management and stakeholders of an ongoing development intervention with indicators of the extent of progress and achievement of objectives and progress in the use of allocated funds.

Secondly, evaluation is then defined as:

... the systematic and objective assessment of an ongoing or completed project, programme or policy, it's design, 
implementation and results. The aim is to determine the relevance and fulfilment of objectives, development efficiency, effectiveness, impact and sustainability, it should provide information that is credible and useful, enabling the incorporation of lessons learned into the decision-making process of both recipients and donors.

The manner in which $M$ \& $E$ is carried out in South Africa is somewhat complex, due to the decentralisation of power and, as such, not much can be carried out in the municipalities without heavy reliance on central government. Mthethwa and Jili (2016) studied how M \& E is carried out in South African municipalities with a special focus on the Mfolozi Municipality, arguing that a lack of effective $M$ \& $E$ is still a major challenge facing the various stakeholders. The result is the inability of the various projects and programmes to meet the set objectives. Therefore, no meaningful impact is felt by the various communities after implementation (Mthethwa \& Jili 2016). This is supported by Maepa (2014) who conducted a study to ascertain how $M$ \& $E$ is carried out in metropolitan municipalities in Gauteng. It was found that, because of the complexity of $M$ \& $E$ in South Africa, it has not been affective due to a lack of political will of elected officials in the municipalities - in addition to a scarcity of requisite skills to conduct effective $M$ \& $E$.

Steytler (2008:767) observed that over-regulation leads to direct commands, effectively eliminating the discretion of the Municipal Council and the managers to find innovative local solutions to developmental challenges. One can thus argue that expecting battling municipalities to judiciously comply with $M$ \& $E$ requirements, is a case of adding yet further responsibilities. However, with specific reference to $M$ \& $E$, the policy framework of government-wide $M \& E$ is cognisant of this fact. The framework points out that as a matter of principle "... the administrative burden of compliance across government should be minimised" and that implementation milestones must be linked to existing capacity and the ability to build capacity over the medium-term. This applies to local municipalities in particular, which, as pointed out, are hamstrung by many capacity and resource constraints. Of course while capacity should not dictate government's normative long-term ideal for $M \& E$, the capacity of local municipalities, specifically, must be factored into implementation plans and risk-managed accordingly.
Namara, Karyeija and Mubangizi (2015:84) note that LGs in many African countries devised new governance approaches, such as network governance and public-private partnerships, in order to include other players in delivering public services. Usually, such external providers have linkages with each other - thus increasing the complexity. These horizontal and vertical relationships involving the public, private and community actors ought to be managed and monitored, and it is this aspect that has seen this interface increasingly becoming the subject of an academic focus. A network of actors rather than a linear arrangement of actors will inevitably require more complex $M$ \& $E$ modalities. What then are the $M$ \& $E$ activities at play in rural municipalities, and how do these pan out in the delivery of basic services?

To start with, the Intergovernmental Relations Framework Act No 13 of 2005 provides a framework for the three spheres of government and all organs of state to facilitate coordination in the implementation of policy and legislation, including: monitoring the implementation of policy and legislation, to ensure a coherent government for the realisation of national priorities. District intergovernmental forums, provided for in the Act, are a space for municipalities to engage and monitor policy outcomes. In particular, Section 26(1) of this Act prescribes that District intergovernmental forums must ensure the coordination and alignment of the strategic and performance plans and priorities, as well as objectives and strategies of the municipalities in the District, and any other matters of strategic importance that affect the interests of the municipalities in the District (Section 26(1). Govender and Pencelia (2011) note that District intergovernmental forums are not effective as $M$ \& $E$ structures, due to the lack of capacity in District and local municipalities.

Perhaps the most instructive legislation on $M$ \& $E$ for municipalities is the Municipal Systems Act 32 of 2000. The Act outlines the details of monitoring and review of the performance management system, and the core components that must be included therein. Section 40 prescribes the monitoring and review of the performance management system and that a municipality must establish mechanisms to monitor and review its performance management system. In Section 41 , it is prescribed that municipalities must set appropriate key performance indicators to be used as yard sticks for measuring performance, including outcomes and impact with regard to the municipality's development priorities and objectives - as specified in 
its IDP. In addition, it further prescribes that municipalities establish a process of regular reporting to: (i) the council, other political structures, political office bearers and staff of the municipality; and (ii) the public and appropriate organs of the state.

Another legislative area for $M \& E$ is the IDP with the Municipal Systems Act 32 of 2000; the Integrated Development Planning Policy sets out the service delivery and economic development priorities of the municipality by establishing key performance indicators and performance targets. The IDP is a description of a comprehensive and strategic plan that directs and informs decision-making processes pertaining to municipal management and development (Municipal Systems Act No. 32 of 2000). In other words, the IDP lays out municipal plans and objectives for the future development of municipalities. It is important to stress that IDP processes involve municipal authorities and the broader municipal community - both of which discuss long-term development goals. IDP processes comprise planning, implementation and evaluation of the development aspects. The process involves considering the existing resources, current problems and their causes - as well as the means to solve the particular problems. For Pieterse (2002), the IDP is a planning methodology linking a statement of purpose with plans, programmes, institutional design and practices - along with monitoring mechanisms and financial flows (Pieterse 2002:5). The information on these issues is obtainable through public meetings with the relevant stakeholders of the municipality - hence the importance of public participation (Municipal Systems Act 32 of 2000). Community members need to be consulted and allowed to take part in issues that affect them directly or indirectly. This also implies that the IDP should mirror the needs and priorities of communities, and, therefore, the authorities will be able to implement and monitor the relevant programmes put in place to deal with those needs.

The main goal of the IDP is to facilitate reduction of poverty levels, which is why it is most relevant for previously marginalised societies. The IDP aims to improve the livelihoods of people. In order to achieve that, there is a need to look at existing conditions in terms of the socio-economic development aspects of the municipal area. What follows is a framework of the required infrastructure services and how these should be established without damaging the environment (Auriacombe and Acron 2015). While municipal authorities, the community and other relevant stakeholders partake in the preparation and implementation of the development plan, the IDP outlines the strategic, tactical, and operational developmental challenges to be achieved over a fiveyear period. The plan, according to Schoeman (2006), must be all-encompassing, with involvement of the relevant stakeholders in ensuring that everyone plays their part. Hence, it is important for each LG to develop their own plan in a manner that enhances their economic growth and addresses the development needs of the community they serve. Therefore, the IDP defines the need for $M$ \& $E$ systems at local level to assess the progress and quality of the inputs, activities, outputs, outcomes and impacts of the implemented policies, programmes and projects (McCarthy 2000:113).

\section{MONITORING AND EVALUATION ARRANGEMENTS - MATATIELE LOCAL MUNICIPALITY}

MLM is located in the Alfred Nzo District Municipality in the Eastern Cape province of South Africa and is located alongside the Drakensberg and Maluti mountain ranges. (Matatiele Local Municipality, 2018). The municipality is predominantly rural in nature and the settlement pattern is characterised by dispersed rural settlements surrounded by subsistence farmlands in the former Transkei region (ECSECC, 2017). Livelihoods are fragile for according to the IHS Markit (in ECSECC, 2017) MLM has an unemployment rate of $30.3 \%$, an $\mathrm{HDI}$ of 0.542 and $72.9 \%$ of its people were living in poverty. This rural, largely poor, municipality is used here to illustrate formal and nonformal processes of $M$ \& $E$ and what important principles can be drawn.

\subsection{Formal Legislated Processes}

As part of enhancing public participation in $M$ \& $E$ activities of the municipality, the MLM embarked on an IDP Community Outreach programme. A local paper reported that the MLM regularly embarks on a programme that gives citizens the power to make their voice heard (Hitchcock 2016). The purpose of these sessions are to present a report on service delivery backlogs and progress per ward. Communities are usually enlightened with regard to the financial year's projects under way, and what priorities, per ward, require revision.

During such community $M$ \& $E$ sessions, teams visiting the respective wards are generally allocated and led by the mayor and members of the executive committee, accompanied by councillors, managers, 
municipal officials, as well as representatives from the District municipality and government departments. Some of the main service delivery concerns highlighted by communities typically relate to infrastructure backlogs, inadequate electrification of surrounding villages, and the shortage of clean drinking water. Following such sessions, the municipality may initiate the addressing of identified issues at the legislated inter-governmental relations forum meeting that sits at the District municipality.

In addition to the legislative requirement of the IDP's community outreach programme, the Municipality established the Local Communicators Forum (LCF) in 2010. Spearheaded by the Matatiele Local Municipality Communications Unit, the LCF comprises the Special Programmes Unit of the municipality; communications officials from the Alfred Nzo District Municipality; a representative from the Office of the Premier of the Eastern Cape Province; and a representative from the Government Communication and Information System (GCIS). In addition, pertinent NGOs and CBOs, as well as community development workers and Ward Support Assistants, participate in the LCF. The LCF is a brainchild of South Africa's Local Government Association (SALGA). At national level, the Communicators Forum provides a platform for municipal communicators to better communicate progress in LG performance and facilitate intermunicipal peer learning. The expectation is that the LCF enables and supports municipal communicators in their important role of informing and educating citizens, while also providing a platform for the sharing of municipal innovations and good practices that will inform improvements in the sector (SALGA 2017).

Both the IDP outreach programme and the LCF are formal and structured spaces through which information on M \& E of the municipality's activities is shared and, by extension, through which communities are themselves involved in $M \& E$ activities.

\subsection{Informal, ad-hoc Processes}

In addition to the above-mentioned formal and legislated for a, it is clear that informal processes have developed in this region. These have developed as a means to specifically ensure $M$ \& $E$ of water resource systems and their conservation. Such ad-hoc, selforganised forums are not unusual in situations where citizens perceive a gap or void in formal structures. Mubangizi and Gray (2011:213) stated that such 'invented spaces' are needed through the construction of informal structures for grassroots community participation and action. While the IDP and local communication forums constitute invited spaces, for the most part, citizens have to work with 'invented spaces' - wherein grassroots communities collaborate with a variety of organisations around a matter of common interest. The Umzimbuvu Catchment Partnership Programme (UCPP), a discussion of which follows, is a case in point.

The Umzimbuvu River catchment is a vulnerable river system in the eastern part of South Africa. The Umzimvubu catchment and river system lies along the northern boundary of the Eastern Cape and extends for over $200 \mathrm{~km}$ from its source in the Drakensberg to its estuary at Port St Johns, where it joins the Indian Ocean. Due to the vital catalytic role the catchment can and should play in the socio-economic development of the region, South Africa, through its Department of Water and Sanitation, has classified the Umzimvubu Water Project as a Strategic Integrated Project (DWA 2013).

The institutional elements governing the river catchment consist of multiple networks, ideologies, and collaborative arrangements of exchange. The network of actors has developed and grown over the past five years in the context of the Umzimbuvu Catchment Partnership Programme (UCPP). The UCPP is a consortium of organisations who, by signing an MOU, commit to collective action to develop and implement a catchment management strategy and restoration plan for the Umzimvubu River corridor. Actors in this consortium derive from community organisations, farmer associations, tourism agencies, conservation activists, local government officers, researchers and academics - to mention but a few. The UCPP members work together to deliver multiple short- and long-term benefits in line with such priorities as integrated rural development, job creation, appropriate pro-poor infrastructure development, and service delivery. A strong component of the programme centres on working with partners and government authorities present within the catchment. In this regard, the "developing of a robust monitoring framework for the catchment through sound research and GIS database development to manage information on the catchment baseline and project impacts is critical" (UCPP 2011:14).

The UCPP comprises 27 organisations with a strong presence in the catchment corridor. Broadly these stakeholders are drawn from state and parastatal 
regulatory bodies, local government (including the Matatiele Local Municipality) and non-governmental organisations. In its $1^{\text {st }}$ phase strategy outline, the UCPP noted that "a structured monitoring and evaluation system supported by a lead organisation can add immeasurable value to the work being done in the catchment most of which is in line with the ideals of the Local municipality" (UCPP 2011:15). Also noted in this strategy report, is that, if well coordinated, an overarching advantage of the consortium is that it potentially strengthens the achievement of outcomes, while reducing budgetary requirements (UCPP 2011:16).

The UCPP is an example of how communities can galvanise around a specific issue and, of their volition, create $M$ \& E processes that are outside the framework of formalised policy and legislative structures.

Both examples from the Matatiele Local Municipality typify collaborative monitoring, in which, according to Cundill and Fabricius (2009:3205), multiple actors are engaged in an ongoing process of data gathering, analysis and decision-making. Such collaborative processes offer an avenue through which social learning objectives for sustainable livelihoods can be pursued.

\section{IMPLICATIONS FOR M \& E PRACTICES IN THE LOCAL MUNICIPALITIES}

The key exposition emerging from the narratives of this article, is that while rural and poorly resourced municipalities stand to gain from strong $M \& E$ models, there are, currently, inadequate $M$ \& $E$ processes being followed by most local municipalities in South Africa, and this could be a result of insufficient requisite skills. As the discussion has shown, this is due to overregulation that effectively eliminates the discretion of the Municipal Council and the managers to find innovative local solutions to developmental challenges. The discussion has shown that collaboration between the local municipality and a diverse set of actors - in which individuals and organisations coordinate actions voluntarily in a self-organising and self-enforcing manner - appears to be evolving as a coping mechanism in poorly resourced municipalities. How can such self-organising processes work, and how can they be nurtured to strengthen $M$ \& $E$ processes?

The fundamental principle is to recognise complexity and non-linearity in the provision of municipal services and therefore seek to integrate variables at more than one spatial and temporal scale (Campbell et al. 2001; Bellamy et al. 2001). Drawing on complexity theory, on Loorbach's principles outlined earlier and on the lessons drawn from $M$ and $E$ processes in Matatiele Local Municipality, the following suggestions are advanced:

To start with, the ideal system should be one that produces information relevant to rural policies, while being reliable and timely enough to inform and influence planning and implementation processes. This requires comprehensive information covering the multidimensional nature of sustainable livelihoods (Solesbury 2003; Carney 1998; Scoones 1998). The sustainable livelihoods framework focuses attention on five sets of assets: natural, human, social, physical and financial. The framework further directs attention to those transforming processes of policy, institutions and processes that enable citizens to transform assets, though livelihood strategies, to desirable and sustainable livelihood outcomes.

An ideal system of $M$ and $E$, based on the sustainable livelihoods framework requires comprehensive information which, from this perspective, interrogates all five facets of the livelihood framework as well as policy and institutional processes of governance. Such comprehensive information should draw on quantitative and qualitative information garnered through participatory methods. As shown in the UCPP structure in Matatiele Local Municipality, an important factor in this regard is that stakeholders collaboratively identify indicators to assess impact in the process of $M \& E$. It is thus beneficial when a variety of skills exist in the network of collaborators as the data collection will depend on time, skills, and the nature of the variable being monitored. Of course, it is critical that the municipality remains a core stakeholder so that, as Loorbach (2007) suggests, there is "steering from the outside with direction from the inside".

Because the complexity of the system is at odds with the formulation of specific objectives and blueprints (Loorbach 2010:167) - flexibility and adjustment to suit the context of the local community are vital. This avoids the 'one-size-fits-all' approach, wherein local municipalities are expected to implement programmes and projects formulated elsewhere.

Furthermore, an ideal $M$ \& $E$ system should be integrated into policy processes by nurturing an organisational culture and institutional framework that engenders the interaction between citizens and local 
government. This appears to be the intention of the Local Communications Forum in Matatiele Local Municipality, discussed earlier. However, as shown in the UCPP case, a much more expansive livelihoods' monitoring network is likely to have more impact. In network theory, a focus on learning about different actor perspectives and a variety of options, is necessary to bring about desired change. An expansive monitoring network will bring together and ensure collaboration between community workers, research institutions, local planners, policy-makers, and civic institutions.

Finally, an ideal $M$ \& E system must have effective mechanisms for providing $M$ \& $E$ information to a variety of users, who, typically, include policy-makers, service providers and, most importantly, the beneficiary citizens. This is perhaps the complex aspect of $M$ \& $E$ for local municipalities, as it requires the articulate and concise condensing of qualitative and quantitative information into a user-friendly form. It also requires that such information be appropriately and honestly packaged for dissemination through a variety of settings. Platforms of academic journals, policy briefs, community newspapers and Facebook postings, along with other such social media platforms, appeal to a variety of users who all need to be kept abreast of the $M \& E$ information of local municipalities.

\section{CONCLUSION}

This article examined how $M$ \& $E$ is practised in local municipalities in South Africa. It is clear that the question of $M \& E$ in South Africa continues to receive considerable attention, due to its importance in assisting municipalities to achieve their developmental mandate. That municipalities require the involvement of a multiplicity of actors operating within a complex network to deliver on their development mandate is further reason why $M$ \& $E$ processes should be above board. Specifically, $M$ \& E frameworks should be accessible to a range of users; they should be participatory and should be empowering for both the beneficiaries and service providers. The current $M$ \& $E$ process in municipalities are mainly monitored through statutory structures whose operational guidelines are laid down by a range of local government legislation and policies. While these are important and beneficial, the discussion in this paper has shown that non statutory structures formed out of ad hoc selforganising models can provide useful forums for monitoring local service provision for sustainable livelihoods. It is clear that without detailed $M$ \& $E$ processes, through an all-inclusive plan, with contributions from various stakeholders at the different levels of government and the local communities, along with skills development and political will - M \& E initiatives will remain one of the failures, with the potential to further marginalise South Africa's rural areas. Collaborative monitoring holds promise in this regard, and deserves greater attention as a means to integrate learning-based approaches in settings where a variety of stakeholders and role-players interact to contribute to the delivery of services. Lastly, and against the backdrop of complexity theory, it is worth exploring how Loorbach's principles can be incorporated in the Integrated Planning processes of rural municipalities. In this regard, community participatory mechanisms need to be developed in the medium- to long-term, after extensive research and testing.

\section{ACKNOWLEDGEMENTS}

I acknowledge the financial assistance of the National Research Foundation (NRF) towards this research. Opinions expressed and conclusions arrived at, are my own and are not necessarily to be attributed to the NRF.

\section{REFERENCES}

Akintoye, A., Beck, M. and C. Hardcastle, eds. 2008. Public-Private Partnerships: Managing Risks and Opportunities. Wiley Online. ISBN: 9780470690703.

https://doi.org/10.1002/9780470690703

Alford, J.L. and J. O'Flynn. 2013. Rethinking Public Service Delivery: Managing with External Providers. Basingstoke, UK: Palgrave Macmillan.

Arntz, T.L. Botes and K. Bekker. 2003. "Strategies for Indigent Policy Formulation and Implementation in Urban Settlements in South Africa." Journal of Public Administration 38(2): 102117.

Atkinson, D. 2003. "Post-Apartheid Local Government Reforms: A Small Town Perspective. Occasional papers reflecting continuing research produced for the Centre for Development and Enterprise". No 8, March.

Attorney General of South Africa (AGSA). 2018. Audit Report of 2018.

Auriacombe, C. and J. Ackron. 2015. Integrated Development and Planning. Johannesburg: University of Johannesburg.

Awortwi N. 2003. "Getting the Fundamentals Wrong: Governance of Multiple Modalities of Basic Services Delivery in Three Ghanaian Cities". PhD Thesis, Institute of Social Studies, The Hague, The Netherlands.

Bellamy, J., Walker, D., McDonald, G. and G. Syme. 2001. "A Systems Approach to the Evaluation of Natural Resource Management Initiatives." Journal of Environmental Management 63: 407-423.

https://doi.org/10.1006/jema.2001.0493

Campbell, B., Sayer, J., Frost, P., Vermeulen, S., Perez, M.R., Cunningham, A.B. and R. Prabhu. 2001. "Assessing the Performance of Natural Resource Systems." Ecology and Society 5: 22 . https://doi.org/10.5751/ES-00316-050222 
Carney, D. (ed.). 1998. Sustainable Rural Livelihoods: What Contribution Can we Make? London: Department for International Development.

Cooperative Government and Traditional Affairs (COGTA). 2009. State of Local Government in South Africa: Overview Report.

Cundill, G. and C. Fabricius. 2009. "Monitoring in Adaptive Comanagement: Toward a Learning Based Approach." Journal of Environmental Management 90(11): 3205-3211. https://doi.org/10.1016/j.jenvman.2009.05.012

Department of Water and Sanitation (DWA). Annual Report 2012/2013. Pretoria. South Africa.

Eastern Cape Socio Economic Consultative Council's (ECSECC). 2017. Socio Economic Outlook Review of Matatiele Local Municipality. https://www.ecsecc.org/documentrepository/ informationcentre/matatiele-local-municipality 76449 . Accessed on $26 / 04 / 2019$

Farlam, P. 2005. Working Together: Assessing Public-Private Partnerships in Africa. https://www.eldis.org/document/ A11528. Accessed on 15/03/2019

Fjeldstad, O.H. 2004. "What's Trust got to do with it? Non-Payment of Service Charges in Local Authorities in South Africa." Journal of Modern African Studies 42(4): 539-562. https://doi.org/10.1017/S0022278X04000394

Govender, I.G. and Y. Penceliah. 2011. "The Role of Monitoring and Evaluation Systems for Service Delivery in Local Government." Administratio Publica 19(4): 4-26.

Hitchcock, L. 2016. "Giving Citizens the Power to Make Their Voice Heard", East Griqualand Fever, 9 December.

Koch, C. and G. Laurent. 1999. "Complexity and the Nervous System." Science 284: 96-98. https://doi.org/10.1126/science.284.5411.96

Liebovitch, L.S. 1998. Fractals and Chaos Simplified for the Life Sciences. New York: Oxford University Press.

Maepa, K.L. 2014. "Performance Monitoring and Evaluation of Metropolitan Municipalities in Gauteng, South Africa.", PhD Thesis, University of Pretoria.

Matatiele Local Municipality. 2018. About Us. Available at: http://www.matatiele.gov.za/ accessed on 15/02/2019).

Matibane, L. 2010. "Improving Service Delivery Through Partnerships Between Local Government, Civil Society and the Private Sector: A Case Study of Imizamo Yethu", Masters Dissertation, Stellenbosch University.

McCarthy, M. 2000. The Implications of Decentralized Delivery for National Monitoring and Evaluation. Development in Africa. pp111 - 116.

Mthethwa, R.M. and N.N. Jili. 2016. "Challenges in Implementing Monitoring and Evaluation (M \& E): The Case of Mfolozi Municipality." African Journal of Public Affairs 9(4): 2016.

Mubangizi, B.C. and M. Gray. 2011. "Putting the 'Public' into Public Service Delivery for Social Welfare in South Africa." International Journal of Social Welfare 20(2): 212-219. https://doi.org/10.1111/j.1468-2397.2010.00760.x
Namara, R.B., Karyeija, G.K. and B.C. Mubangizi. 2015. "Network Governance and Capacity of Local Governments to Deliver LED in Uganda." Commonwealth Journal of Local Governance 18: 82-107. https://doi.org/10.5130/cjlg.v0i18.4844

Ndzelu, L. 2016. "The Effect of Legislative Compliance on Infrastructure Service Delivery: The Case of Matatiele Local Municipality." Doctoral dissertation, Stellenbosch University.

Pieterse, J.N. 2002. "Global Inequality: Bringing Politics Back in." Third World Quarterly 23(6): 1023-1046. https://doi.org/10.1080/0143659022000036667

Pieterse, J.N. 2012. "Using Programme Theory for Complicated and Complex Programmes." Evaluation 14:1: 29-48. https://doi.org/10.1177/1356389007084674

Republic of South Africa (RSA). 1996. Constitution of the Republic of South Africa as adopted by the Constitutional Assembly on 8 May 1996. ISBN: 0-260-20716-7. Pretoria: Government Printers.

Republic of South Africa. Ministry for Provincial Affairs and Constitutional Development. 1998. White Paper on Local Government, Pretoria.

Ruiters, C. and M.P. Matji. 2016. Public-Private Partnership Conceptual Framework and Models for the Funding and Financing of Water Services Infrastructure in Municipalities From Selected Provinces in South Africa. Water SA 42(2): 291-305. https://doi.org/10.4314/wsa.v42i2.13

Schoeman, C.B. 2006. "Integrated Development Plan Management: A Case of Strategic Management." Dissertation, North West University.

Scoones, I. 1998. "Sustainable Rural Livelihoods: A Framework for Analysis". Working Paper 72. Brighton, UK: Institute for Development Studies.

Sebola, M.P. 2015. Local Government in Post-Apartheid South Africa: Some Critical Perspectives. Batalea Publishers

Solesbury, W. 2003. "Sustainable Livelihoods: A Case Study of the Evolution of DFID Policy." London: Overseas Development Institute.

Statistics South Africa. 2017. Non Financial Census of Municipalities Media release. March, 2017. Available at http://www.statssa.gov.za/?p=9932. Retrieved on 20 March 2019.

Steytler, N. 2005. "The Powers of Local Government in Decentralised Systems of Government: Managing the 'Curse of Common Competencies'." Comparative and International Law Journal of Southern Africa 38(2): 271-284.

Svyantek, D.J. and L.L. Brown. 2000. "A Complex-Systems Approach to Organizations." Current Directions in Psychological Science 9(2): 69-74 https://doi.org/10.1111/1467-8721.00063

\section{DOl: https://doi.org/10.6000/1929-7092.2019.08.48}

(C) 2019 Betty C. Mubangizi; Licensee Lifescience Global.

This is an open access article licensed under the terms of the Creative Commons Attribution Non-Commercial License (http://creativecommons.org/licenses/by-nc/3.0/) which permits unrestricted, non-commercial use, distribution and reproduction in any medium, provided the work is properly cited. 